\title{
Reprocessing of LiH in Molten Chlorides
}

\author{
Patrick J. Masset ${ }^{\mathrm{a}, \mathrm{b}}$, Armand Gabriel ${ }^{\mathrm{a}, \mathrm{c}}$, and Jean-Claude Poignet $^{\mathrm{a}}$ \\ ${ }^{a}$ Laboratoire d'Electrochimie et de Physico-chimie des Matériaux et Interfaces, \\ Ecole Nationale Supérieure d'Electrochimie et d'Electrométallurgie de Grenoble, \\ Institut National Polytechnique de Grenoble, BP 75, 1130, rue de la Piscine, \\ F-38402 Saint Martin d'Hères, France \\ b Present address: Karl Winnacker Institut der Dechema e.V., Theodor-Heuss Allee 25, \\ D-60486 Frankfurt am Main, Germany \\ ${ }^{c}$ Present address: Laboratoire de Thermodynamique et de Physico-chimie des Matériaux (LTPCM), \\ Ecole Nationale Supérieure d'Electrochimie et d'Electrométallurgie, Institut National \\ Polytechnique de Grenoble, 1130, rue de la Piscine, BP 75, F-38402 Saint Martin d'Hères, France \\ Reprint requests to P. J. M.; Fax: + 4969 7564-362/388; E-mail: masset@ dechema.de
}

Z. Naturforsch. 63a, $377-384$ (2008); received November 3, 2007

Presented at the EUCHEM Conference on Molten Salts and Ionic Liquids, Hammamet, Tunisia, September 16-22, 2006.

$\mathrm{LiH}$ was used as inactive material to stimulate the reprocessing of lithium tritiate in molten chlorides. The electrochemical properties (diffusion coefficients, apparent standard potentials) were measured by means of transient electrochemical techniques (cyclic voltammetry and chronopotentiometry). At $425{ }^{\circ} \mathrm{C}$ the diffusion coefficient and the apparent standard potential were $2.5 \cdot 10^{-5} \mathrm{~cm}^{2} \mathrm{~s}^{-1}$ and $-1.8 \mathrm{~V}$ vs. $\mathrm{Ag} / \mathrm{AgCl}$, respectively. For the process design the $\mathrm{LiH}$ solubility was measured by means of DTA to optimize the LiH concentration in the molten phase. In addition electrolysis tests were carried out at $460{ }^{\circ} \mathrm{C}$ with current densities up to $1 \mathrm{~A} \mathrm{~cm}^{-2}$ over $24 \mathrm{~h}$. These results show that $\mathrm{LiH}$ may be reprocessed in molten chlorides consisting in the production of hydrogen gas at the anode and molten metallic lithium at the cathode.

Key words: LiH; Molten Salt; Electrolysis; Hydrogen; Litium.

\section{Introduction}

$\mathrm{LiH}$ is considered as an attractive material for industrial applications due to its highly reducing character and its low molecular weight. Several applications were envisaged using $\mathrm{LiH}$ as raw material: electrical energy production, hydrogen storage, metallic hydride formation in molten salts $[1,2]$. The first reliable studies showed that $\mathrm{LiH}$ becomes an electrical conductor near its melting point [3] and might be used in electrolysis processes [4-6]. It has been shown that the electrolysis of $\mathrm{LiH}$ provides metallic lithium at the cathode and hydrogen gas at the anode (quantitatively determined from the transformation of hydride into hydrogen). Later the solubility of $\mathrm{LiH}$ in the $\mathrm{LiCl}-\mathrm{KCl}$ eutectic was measured by Plambeck et al. [7] using transient electrochemical techniques at $375{ }^{\circ} \mathrm{C}$. At this temperature the solubility of $\mathrm{LiH}$ in the $\mathrm{LiCl}-\mathrm{KCl}$ eutectic is close to $5 \mathrm{~mol} \%$. Recently, the electrochemical properties of $\mathrm{LiH}$ were re-investigated in different molten salts. The literature data (diffusion coefficients, appar- ent standard potential, electrode nature, ...) are summarized in Table 1. The effect of the electrode materials was also studied. It has been shown that the solubility of hydrogen in metals decreases in the following sequence: $\mathrm{Ni}>\mathrm{Fe}>\mathrm{Co}>\mathrm{Cu}$ [8]. A mechanism for the oxidation of the hydride anion was proposed. First, the hydride is oxidized into atomic hydrogen adsorbed on the metallic working electrode according to Sievert's law. Then, two adsorbed hydrogen atoms combine to form hydrogen gas which is released in the melt. This model, including the chemical reaction after the redox process, differs from previous studies [4-6], where a simple electrochemical reaction was envisaged. Thermodynamic quantities (Gibbs free energy, enthalpy and entropy) were derived from electrochemical measurements (cyclic voltammetry) [9]. The activity coefficient, $\gamma_{\mathrm{H}^{-}}$, in the dilute $\mathrm{H}^{-}$ion region $\left(0.002<X_{\mathrm{H}^{-}}<0.080\right)$ was found close to 7.1 (in pure liquid $\mathrm{LiH}, \gamma_{\mathrm{H}^{-}}$is taken equal to unity). It revealed the strong nonideal behaviour of $\mathrm{LiH}$-based solutions and the strong interactions in the bath in dilute solutions. 
Table 1. Summary of electrochemical data.

\begin{tabular}{|c|c|c|c|c|c|}
\hline$T\left({ }^{\circ} \mathrm{C}\right)$ & $\begin{array}{l}\text { Redox potential of } \mathrm{H}^{-} / \mathrm{H}_{2} \text { couple } \\
\left(\mathrm{V} \text { vs. } \mathrm{Li} / \mathrm{Li}^{+}\right)\end{array}$ & Electrolyte & Diffusion coefficient $\left(10^{5} \mathrm{H}^{-} / \mathrm{cm}^{2} \mathrm{~s}^{-1}\right)$ & $\begin{array}{c}\text { Electrode } \\
\text { material }\end{array}$ & Ref. \\
\hline 375 & $0.5-0.7$ & LiCl-KCl & 1.67 & Mo & [7] \\
\hline & 0.65 & $\mathrm{LiCl}-\mathrm{KCl}$ & $D_{\mathrm{H}^{-}}=4.4 \cdot 10^{-3} \exp \left(-2.8 \cdot 10^{4} / R T\right)^{*}$ & $\mathrm{Fe}$ & [8] \\
\hline 450 & - & $\mathrm{LiCl}-\mathrm{KCl}$ & $\begin{array}{c}\text { Henry's law, } \kappa_{\mathrm{H}}=5.68 \cdot 10^{-12} \mathrm{~mol} \mathrm{~cm}{ }^{3} \mathrm{~Pa}^{-1}, \\
\mathrm{D}_{\mathrm{H}_{2}}=3.18\end{array}$ & $\mathrm{Ni}$ & [9] \\
\hline 450 & $>0.55$ & $\mathrm{LiCl}-\mathrm{KCl}$ & & Mo & [10] \\
\hline 300 & $>0.6$ & LiI-KI & No data available & $\mathrm{Ni}$ & [11] \\
\hline 550 & Electrolysis potential $0.5 \mathrm{~V} \mathrm{vs.} \mathrm{Li}^{+} / \mathrm{Li}$ & LiF-NaF-KF & $(\mathrm{CM}): 0.9,(\mathrm{CV}): 1,(\mathrm{CP}): 0.7,(\mathrm{CA}): 0.7$ & $\mathrm{Ni}$ & [12] \\
\hline 400 & $E^{\circ}\left(\mathrm{H}_{2} / \mathrm{H}^{-}\right)=0.258\left(p_{\mathrm{H}_{2}}=1 \mathrm{~atm}, X_{\mathrm{H}^{-}}=1\right)$ & LiCl-KCl & - & $\mathrm{Ni}$ & [13] \\
\hline 450 & & $\mathrm{LiCl}-\mathrm{KCl}$ & $(\mathrm{CM}): 2.0,(\mathrm{CV}): 2.2,(\mathrm{CP}): 1.7,(\mathrm{CA}): 1.9$ & Mo & [14] \\
\hline $425-550$ & $\begin{array}{c}E^{\circ}\left(\mathrm{H}_{2} / \mathrm{H}^{-}\right)=0.625-0.585 \cdot 10^{-3} / T(\mathrm{~K}) \\
\left(p_{\mathrm{H}_{2}}=1 \mathrm{~atm}\right)\end{array}$ & $\begin{array}{c}\mathrm{LiCl}-\mathrm{KCl} \\
\mathrm{LiCl}-\mathrm{CsCl} \\
\mathrm{LiCl}-\mathrm{KCl}-\mathrm{CsCl}\end{array}$ & $\begin{array}{l}D_{\mathrm{H}^{-}}=3.08 \cdot 10^{-3} \exp \left(-3.147 \cdot 10^{4} / R T\right)^{*} \\
D_{\mathrm{H}^{-}}=2.51 \cdot 10^{-2} \exp \left(-4.388 \cdot 10^{4} / R T\right)^{*} \\
D_{\mathrm{H}^{-}}=7.51 \cdot 10^{-3} \exp \left(-3.734 \cdot 10^{4} / R T\right)^{*}\end{array}$ & $\mathrm{Cu}$ & [15] \\
\hline
\end{tabular}

* True diffusion coefficient without the $10^{5}$ parameter scale.

The aim of this work is to determine the basic electrochemical properties of dissolved hydrid in the molten $\mathrm{LiCl}-\mathrm{KCl}$ eutectic in view of carrying out the reprocessing of $\mathrm{LiH}$ in molten chlorides.

\section{Experimental}

\subsection{Chemicals}

Lithium hydride ( $\mathrm{LiH},>98 \%$ purity from Acros) was used as received. It was stored in a closed pan in a glove box under argon atmosphere. Silver chloride $(\mathrm{AgCl},>99.9 \%$ purity from Strem Chemicals), used for the reference electrode, was stored in a black container inside a glove box. Mo and $\mathrm{W}$ wires $(1 \mathrm{~mm}$ in diameter), used as electrode materials, were both purchased from Alfa-Aesar. Lithium chloride $(\mathrm{LiCl},>$ $99.6 \%$ purity) and potassium chloride $(\mathrm{KCl},>99.5 \%$ purity) were purchased from Strem Chemicals and Normapur-Prolabo, respectively. The salts were dried individually at $200{ }^{\circ} \mathrm{C}$ for $15 \mathrm{~h}$ under vacuum to remove the residual water. The drying temperature was fixed at $200{ }^{\circ} \mathrm{C}$, a temperature which was considered high enough to remove water issued from the decomposition of hydrates [16]. Potassium chloride forms no hydrates $[17,18]$, and its water uptake kinetics is low compared to that of lithium-based salts [19]. Lithium chloride and potassium chloride were mixed in the required proportions $(58.8: 41.2 \mathrm{~mol} \%)$ [20] to prepare the $\mathrm{LiCl}-\mathrm{KCl}$ eutectic. The melt was slowly heated under vacuum up to its melting point to remove the residual moisture. Once the salt melted, the cell was flushed with dry argon, and dry argon bubbling was maintained in the molten salt for $15 \mathrm{~h}$ at $450{ }^{\circ} \mathrm{C}$.

\subsection{Apparatus}

The electrochemical set-up is depicted in Figure 1. An Eurotherm controller combined with a chromelalumel thermocouple in an $\mathrm{Al}_{2} \mathrm{O}_{3}$ sheath maintained the melt temperature with an estimated accuracy of $\pm 2{ }^{\circ} \mathrm{C}$. The working electrode consisted of a $\mathrm{W}$ wire ( $1 \mathrm{~mm}$ in diameter) dipped into the bath. The activity of the electrode surface was determined after each experiment by measuring the immersion depth of the electrode in the molten salt. The auxiliary electrode was made of an Mo wire (1 $\mathrm{mm}$ in diameter) bent into a spiral shape. $\mathrm{Ag} / \mathrm{AgCl}\left(1 \mathrm{wt} \%\right.$, or $X_{\mathrm{AgCl}}=0.0039$ in $\mathrm{LiCl}-\mathrm{KCl}$ ) was used as reference electrode [21,22]. The Ag wire, the alumina tube sheath, as well as the $\mathrm{AgCl}(1 \mathrm{wt} \%)-\mathrm{LiCl}-\mathrm{KCl}$ salt were placed inside a thin Pyrex ${ }^{\circledR}$ (Duran) tube dipped in the solution.

\subsection{Techniques}

Transient electrochemical techniques, i.e. cyclic voltammetry (CV) and chronopotentiometry (CP), were carried out in an electrochemical cell having a three-electrode set-up. The measurements were performed with a Princeton Applied Research PAR 273 potentiostat equipped with the EG\&G M270 electrochemical software. For semi-integral analysis of cyclic voltammograms by the convolution method (CM), the Condecon software was used.

The differential thermal analysis (DTA) experiments were performed using a Netzsch thermal analyzer at $10{ }^{\circ} \mathrm{C} \mathrm{min}-1$. Samples and pans were prepared in a glove box under argon atmosphere. The experiments were carried out in a dynamic atmosphere (flow rate of $1.25 \mathrm{lh}^{-1}$ ) of dry helium (less than $5 \mathrm{ppm} \mathrm{H}_{2} \mathrm{O}$ ) 


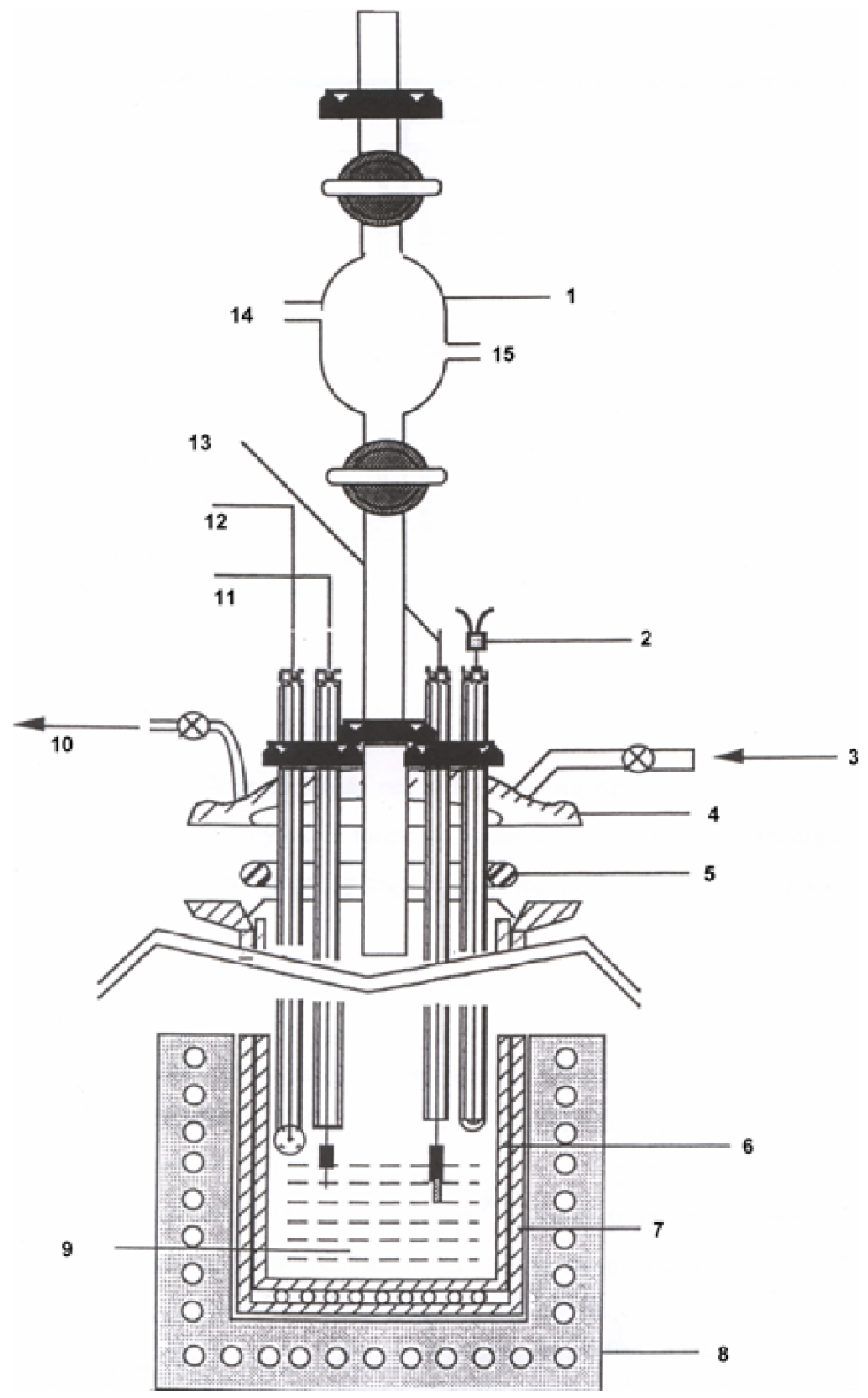

Fig. 1. Electrochemical apparatus: 1, lock-chamber (for adding $\mathrm{LiH}$ ); 2, thermocouple; 3, argon inlet; 4, bottom of the cell; 5 , toric gasket; 6 , Ni crucible; 7, $\mathrm{Al}_{2} \mathrm{O}_{3}$ crucible; 8, furnace; 9, molten salt; 10, argon outlet; 11, working electrode; 12, reference electrode; 13 , counter electrode; 14, lock-chamber argon outlet; 15, lock-chamber argon inlet.

on $30 \mathrm{mg}$ samples with tight pans. Crucibles and the cover were made of stainless steel whereas the gasket was made of nickel.

\section{Results and Discussion}

\subsection{Electrochemical Determinations}

\section{General Features}

On a W electrode the oxidation of $\mathrm{H}^{-}$anions into $\mathrm{H}_{2}$ takes place at a potential close to $-1.85 \mathrm{~V}$ vs. $\mathrm{Ag} / \mathrm{AgCl}$ and the reduction of $\mathrm{H}_{2}$ gas at the slightly lower potential of $-2 \mathrm{~V}$ vs. $\mathrm{Ag} / \mathrm{AgCl}$ (see Fig. 2), whereas the $\mathrm{Li}^{+} / \mathrm{Li}$ and $\mathrm{Cl}_{2} / \mathrm{Cl}^{-}$redox systems are situated at potentials close to -2.6 and $+1.2 \mathrm{~V}$ vs. $\mathrm{Ag} / \mathrm{AgCl}$, respectively. Before the addition of lithium hydride, no peak was observed in the region of oxide potentials $(+0.2 \mathrm{~V}$ vs. $\mathrm{Ag} / \mathrm{AgCl}$ at $425^{\circ} \mathrm{C}$ [23]). The initial bath was considered as free of oxides. These results agree with previous determinations by Plambeck et al. [7] ( $E=$ $-1.7 \mathrm{~V}$ vs. $\mathrm{Ag} / \mathrm{AgCl}$ at $\left.375{ }^{\circ} \mathrm{C}\right)$. The redox system 

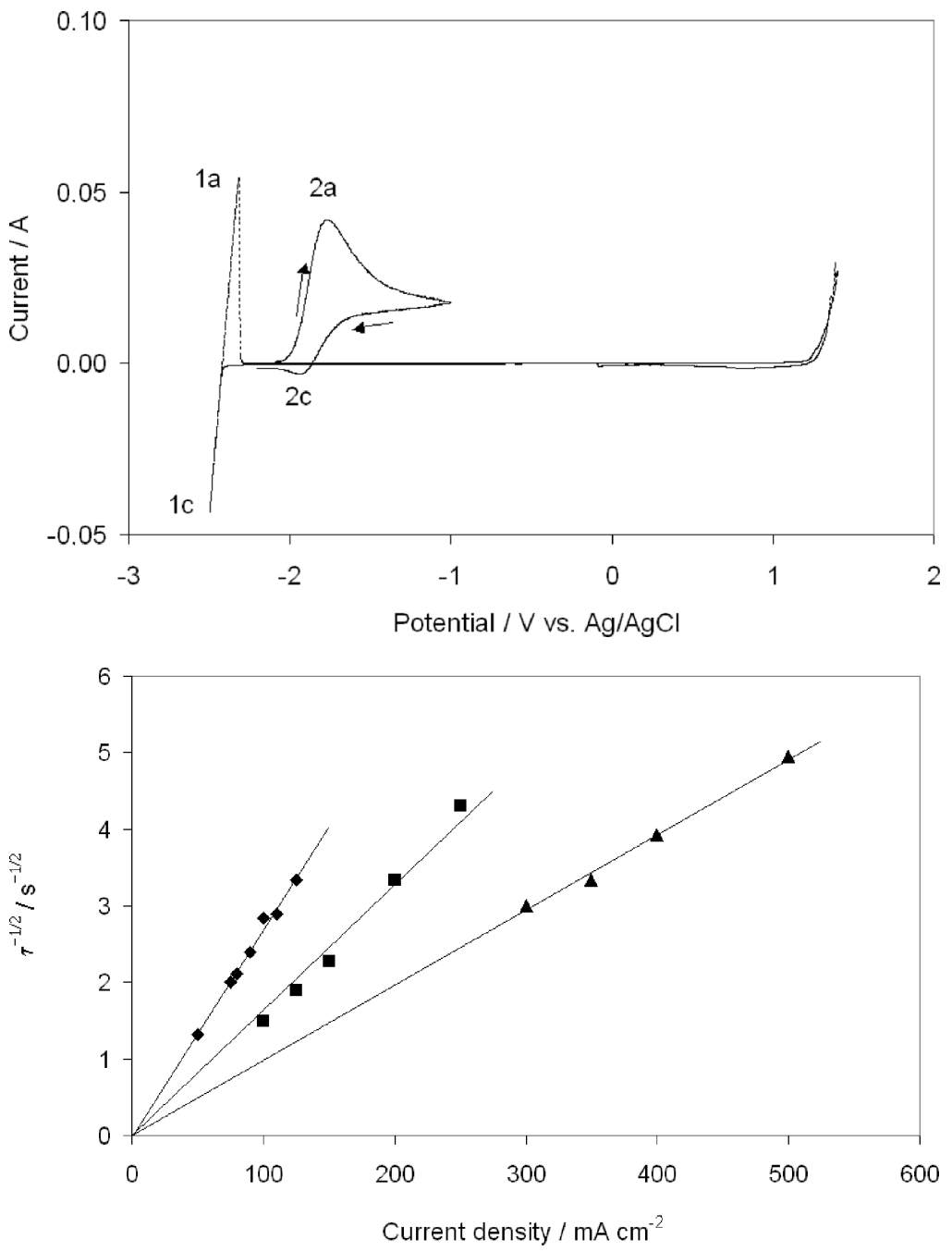

Fig. 2. Typical voltammogram recorded at $425{ }^{\circ} \mathrm{C} ; C^{*}=1 \mathrm{~mol} \%$ (full line), pure $\mathrm{LiCl}-\mathrm{KCl}$ eutectic (dotted line); reference electrode, $\mathrm{Ag} / \mathrm{AgCl}$ $\left(0.75 \mathrm{~mol} \mathrm{~kg}^{-1}\right)$; counter electrode, Mo; working electrode, $\mathrm{W} ; S=0.34 \mathrm{~cm}^{2}$.

Fig. 3. Dependence of $\tau^{-1 / 2}$ on $i ; T=$ $425{ }^{\circ} \mathrm{C}$; reference electrode, $\mathrm{Ag} / \mathrm{AgCl}$ $\left(0.75 \mathrm{~mol} \mathrm{~kg}^{-1}\right)$; counter electrode, Mo; working electrode, $\mathrm{W} ; S=0.34 \mathrm{~cm}^{2}$; (४) $C^{*}=1 \mathrm{~mol} \%$; (口) $C^{*}=1.6 \mathrm{~mol} \%$; (ム) $C^{*}=2.55 \mathrm{~mol} \%$.
$\mathrm{H}_{2} / \mathrm{H}^{-}$was considered as reversible up to $0.75 \mathrm{~V} \mathrm{~s}^{-1}$, since the potential peak Ep $(\mathrm{CV})$ and the plateau potential (CP) remained constant. For a potential scan rate higher than $0.75 \mathrm{~V} \mathrm{~s}^{-1}$ the value of Ep $(\mathrm{CV})$ varied linearly with the potential scan rate (experimental slope: $61 \mathrm{mV} /$ decade; theoretical slope: $60 \mathrm{mV} /$ decade [24]), and the system became quasi-reversible. All the determinations (diffusion coefficient, apparent standard potential) were made in the potential scan rate range where the system could be considered as reversible, e.g. for a potential scan rate lower than $0.75 \mathrm{~V} \mathrm{~s}^{-1}$.

\section{Diffusion Coefficients}

The diffusion coefficients were measured at $425{ }^{\circ} \mathrm{C}$ by chronopotentiometry. For the range of current den- sities investigated, Sand's law

$$
i \sqrt{\tau}=\frac{1}{2} n F S C^{*} \sqrt{\pi D_{\mathrm{H}^{-}}}=C^{t}
$$

was verified (Fig. 3) [25]. From cyclic voltammograms the diffusion coefficients were derived using the Randles-Sevick relation [26]

$$
I_{\mathrm{p}} / \sqrt{v}=0.446(n F)^{3 / 2}(R T)^{-1 / 2} C^{*} S D_{\mathrm{H}^{-}}{ }^{1 / 2} .
$$

The curves do not cross exactly the origin. This was ascribed to a partial consumption of lithium hydride by the silica of the reference electrode compartment. The same behaviour was pointed out by Nohira et al. [10]. For the calculations it should lead to a diffusion coefficient slightly higher than the true value, as the lithium 


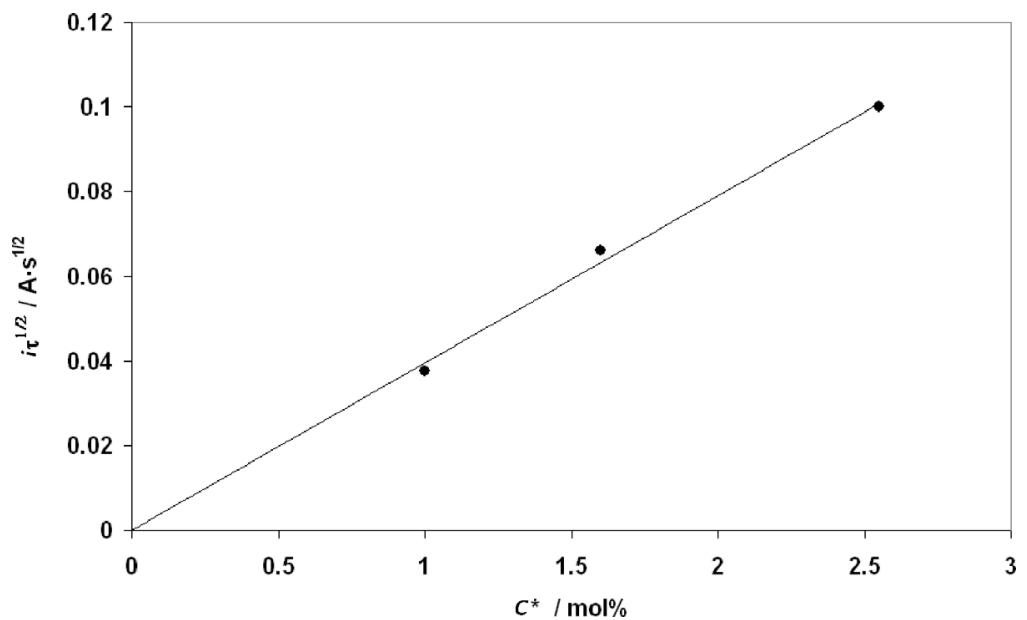

Fig. 4. Dependence of $i \tau^{-1 / 2}$ on the $\mathrm{LiH}$ concentration $C^{*}$. hydride concentration decreases. It should be pointed out that the error in the determination of the diffusion coefficient due to the slight change in the concentration $C^{*}$ remains lower than the normal scattering usually observed in the determination of such features. In addition, using semi-integration of cyclic voltammogramms, the convoluted current was calculated according to Savéant's procedure [27,28]:

$$
m(t)=\frac{1}{\pi^{1 / 2}} \int_{0}^{t} \frac{i(t)}{(t-u)^{1 / 2}} \mathrm{~d} u,
$$

where $m$ is the convoluted current, $i(t)$ the current density versus time $(t)$ and $u$ the time integration variable. The diffusion coefficients were derived on the basis of the limiting current

$$
m^{*}=n F S C^{*} D^{1 / 2} \text {. }
$$

From the CP measurements it is obvious that the diffusion coefficient of $\mathrm{H}^{-}$is independent of the lithium hydride concentration (Fig. 4). Values obtained for each technique are reported in Table 2. The average value obtained by $\mathrm{CV}, \mathrm{CP}$ and $\mathrm{CM}$ techniques is close to $2.2 \cdot 10^{-5} \mathrm{~cm}^{2} \mathrm{~s}^{-1}$. It agrees with the published data: $3.5 \cdot 10^{-5} \mathrm{~cm}^{2} \mathrm{~s}^{-1}$ at $425^{\circ} \mathrm{C}[8]$.

\section{Apparent Standard Potentials}

The apparent standard potential, $E^{\circ *}$, and the number of electrons exchanged, $n$, were deduced from $\mathrm{CP}$, $\mathrm{CV}$ (Fig. 5) and CM measurements, using the relationships derived from the Nernst equation for a reversible soluble/soluble redox system. From CP experiments
Table 2. Apparent standard potential of the $\mathrm{H}_{2} / \mathrm{H}^{-}$redox system, diffusion coefficient of $\mathrm{H}^{-}$in $\mathrm{LiCl}-\mathrm{KCl}$ and number of electrons exchanged during the oxidation of $\mathrm{H}^{-}$at $425^{\circ} \mathrm{C}$.

\begin{tabular}{cccc}
\hline Method & $\begin{array}{c}E^{\circ *} \\
\text { (V vs. ref.) }\end{array}$ & $\begin{array}{c}\text { Diffusion coefficient } \\
\left(10^{5} D_{\mathrm{H}^{-}} / \mathrm{cm}^{2} \mathrm{~s}^{-1}\right)\end{array}$ & $\begin{array}{c}\text { Number of } \\
\text { electrons exchanged }\end{array}$ \\
\hline $\mathrm{CV}$ & -1.83 & $3 \pm 1$ & 1.01 \\
$\mathrm{CM}$ & -1.85 & $1 \pm 0.7$ & - \\
$\mathrm{CP}$ & -1.84 & $2.5 \pm 0.5$ & 1.08 \\
\hline
\end{tabular}

the apparent standard potential was calculated according to

$$
E=E_{\tau / 4}-\frac{R T}{n F} \ln \left(\frac{\tau^{1 / 2}-t^{1 / 2}}{t^{1 / 2}}\right) .
$$

For the calculations of the apparent standard potential using the convolution technique, the diffusion coefficients of $\mathrm{H}_{2}$ used in (5) were taken from the literature. The hydrogen diffusion coefficient in the $\mathrm{LiCl}-\mathrm{KCl}$ eutectic at $450^{\circ} \mathrm{C}$ was evaluated to be $1.64 \cdot 10^{-5} \mathrm{~cm}^{2} \mathrm{~s}^{-1}$ and $3.2 \cdot 10^{-5} \mathrm{~cm}^{2} \mathrm{~s}^{-1}$ by Ito and Hasegawa [9] and Liaw et al. [29]:

$$
E=E^{\circ}+\frac{R T}{n F} \ln \left(D_{\mathrm{H}_{2}} / D_{\mathrm{H}^{-}}\right)+\frac{R T}{n F} \ln \left(\frac{m^{*}-m(t)}{m(t)}\right) .
$$

Values of the apparent standard potentials are summarized in Table 2. The mean value of the apparent standard potential is close to $-1.84 \mathrm{~V}$ vs. $\mathrm{Ag} / \mathrm{AgCl}$. The number of electrons exchanged was close to unity. This confirms the one electron mechanism for the oxidation process of hydride into hydrogen gas on an inert tungsten electrode:

$$
\mathrm{H}^{-} \leftrightarrows 1 / 2 \mathrm{H}_{2}+\mathrm{e}^{-}
$$



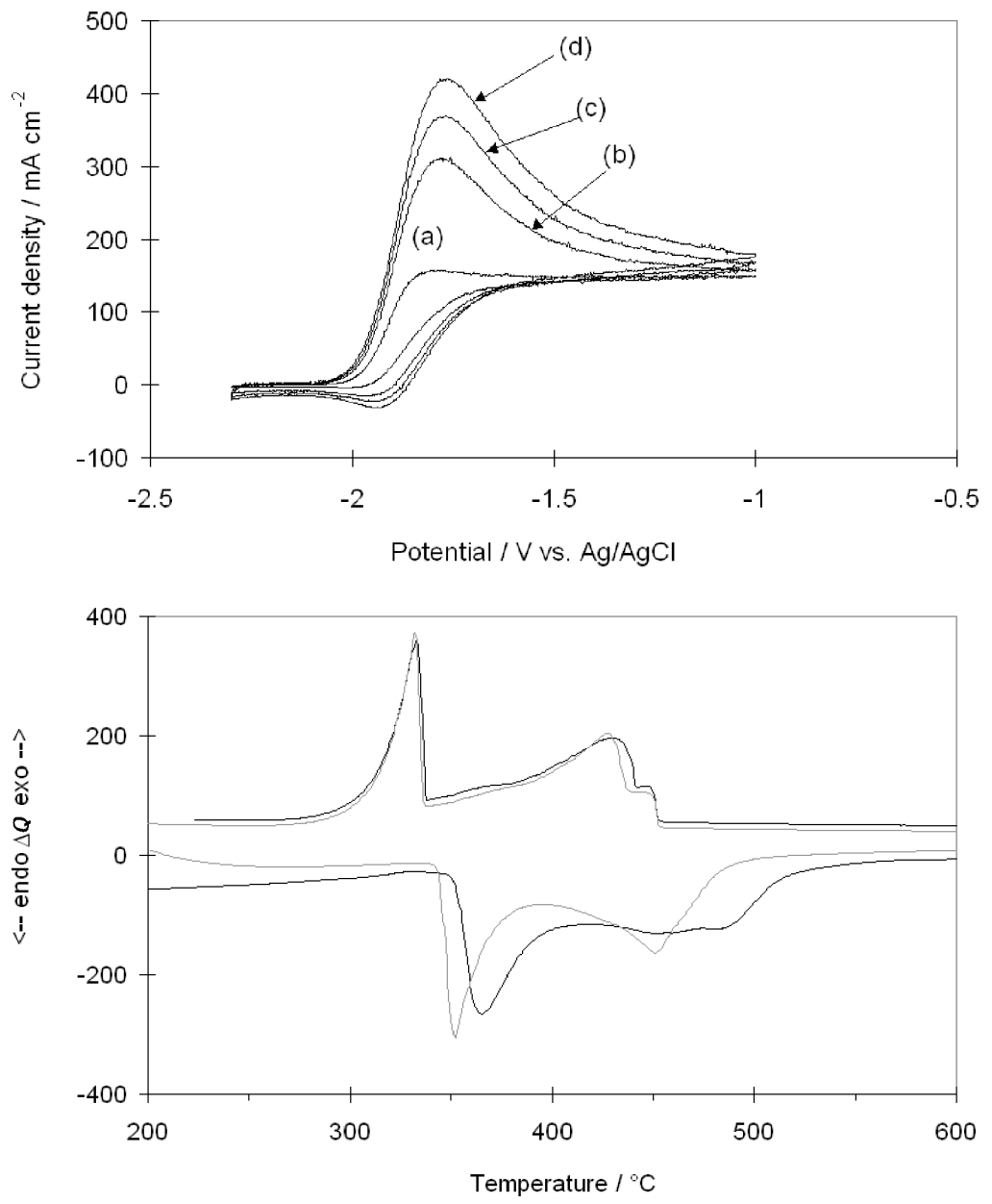

Fig. 5. Cyclic voltammograms recorded at different potential scan rates in the $\mathrm{LiCl}-\mathrm{KCl}$ eutectic at $425{ }^{\circ} \mathrm{C}$; $C^{*}=1 \mathrm{~mol} \%$; reference electrode, $\mathrm{Ag} / \mathrm{AgCl}\left(0.75 \mathrm{~mol} \mathrm{~kg}^{-1}\right)$; counter electrode, Mo; working electrode, $\mathrm{W} ; \mathrm{S}=$ $0.34 \mathrm{~cm}^{2}$; (a) $0.1 \mathrm{~V} \mathrm{~s}^{-1}$; (b) $0.5 \mathrm{~V} \mathrm{~s}^{-1}$; (c) $0.75 \mathrm{~V} \mathrm{~s}^{-1}$, (d) $1 \mathrm{~V} \mathrm{~s}^{-1}$.

Fig. 6. Recorded DTA signal of a mixture of $\mathrm{LiH}: \mathrm{LiCl}: \mathrm{KCl}(11: 73.2$ : $15.8 \mathrm{~mol} \%)$; first thermal cycle, dotted line; second thermal cycle, full line.

\subsection{Reprocessing of $\mathrm{LiH}$ in an $\mathrm{LiCl}-\mathrm{KCl} \mathrm{Bath}$}

\section{Solubility of $\mathrm{LiH}$ in $\mathrm{LiCl}-\mathrm{KCl}$}

The solubility of $\mathrm{LiH}$ in $\mathrm{LiCl} / \mathrm{KCl}$ mixtures was investigated by DTA. Selected compositions were analyzed in order to determine the shape of the liquidus curve of the ternary system $\mathrm{LiH}-\mathrm{LiCl}-\mathrm{KCl}$. It was thought reasonable to carry out the reprocessing of $\mathrm{LiH}$ up to $500{ }^{\circ} \mathrm{C}$ regarding the corrosion phenomena due to $\mathrm{LiH}$ and salt evaporation at higher temperatures. For each selected composition two thermal cycles were carried out (Fig. 6). Reproducible measurements within $\pm 5{ }^{\circ} \mathrm{C}$ were obtained. The shape of the liquidus curve was determined for the whole range of compositions in the ternary system. The $\mathrm{LiH}-\mathrm{LiCl}-\mathrm{KCl}$ system forms a ternary eutectic (Fig. 7) and the eutectic temperature is close to $(345 \pm 3)^{\circ} \mathrm{C}$ (mean value of 10 measurements).

\section{Electrolysis Tests}

Electrolysis tests were carried out at $460{ }^{\circ} \mathrm{C}$ with the electrolysis cell depicted in Figure 8. According to the DTA measurements the composition of the LiH$\mathrm{LiCl}-\mathrm{KCl}$ bath was fixed to $20-65-15 \mathrm{~mol} \%$. The electrolysis cell consisted of an $\mathrm{Ni}$ grid cathode and a stainless steel anode. The electrodes were separated to avoid the recombination of the hydrogen formed at the anode and the molten metallic lithium produced at the cathode. Electrolysis at $1 \mathrm{~A} \mathrm{~cm}^{-2}$ was maintained over $24 \mathrm{~h}$ with a constant cell potential close to $1.25 \mathrm{~V}$ (Fig. 9). The cell potential was in agreement with the electrochemical determinations. At $2 \mathrm{~A} \mathrm{~cm}^{-2}$ the potential shifted to the $\mathrm{Cl}_{2} / \mathrm{Cl}^{-}$redox system due to the hydride ion depletion of the electrode/electrolyte interface. At $1 \mathrm{~A} \mathrm{~cm}^{-2}$ the interface depletion was not reached after $24 \mathrm{~h}$ ( $\mathrm{LiH}$ amount calculated to be consumed after $24 \mathrm{~h}$ ). This means that the efficiency of the 


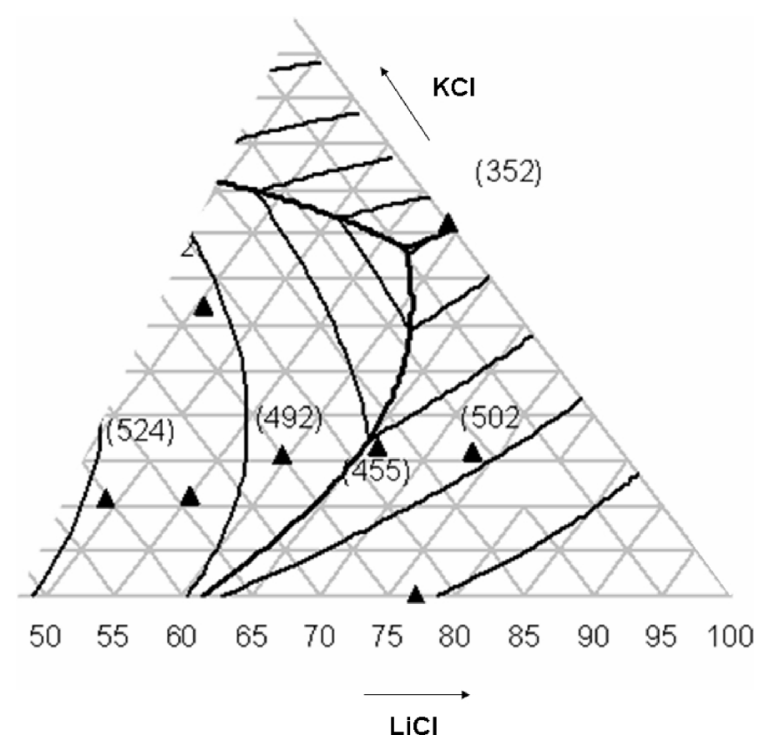

Fig. 7. Projection of the calculated isotherm lines of the liquid in the LiCl-rich corner of the ternary system LiH-LiCl$\mathrm{KCl}$ and the experimental points $(\boldsymbol{\Delta})$. The experimental temperatures are given in brackets (in ${ }^{\circ} \mathrm{C}$ ).

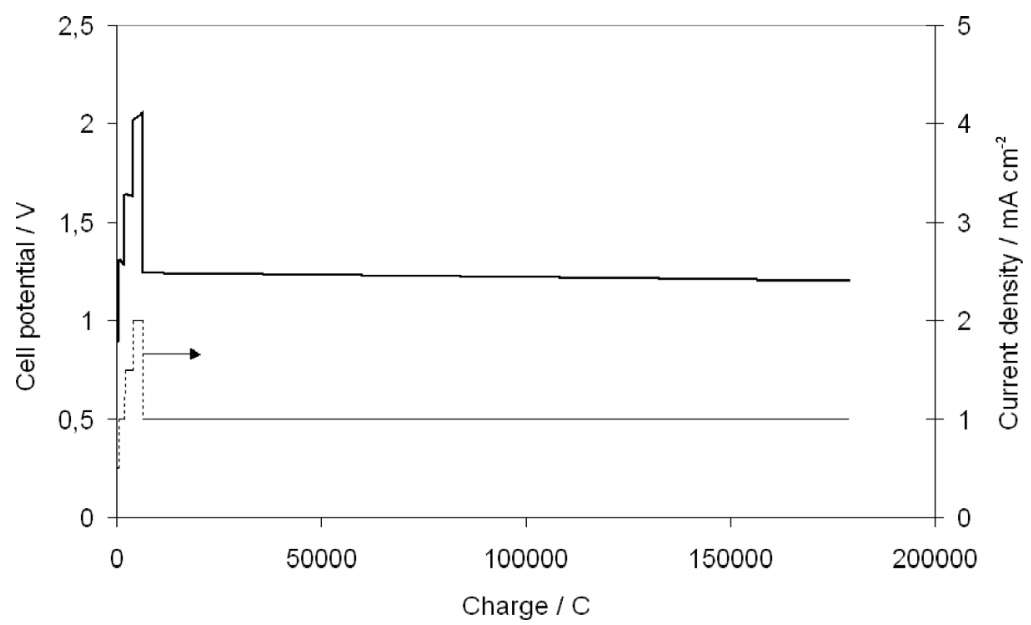

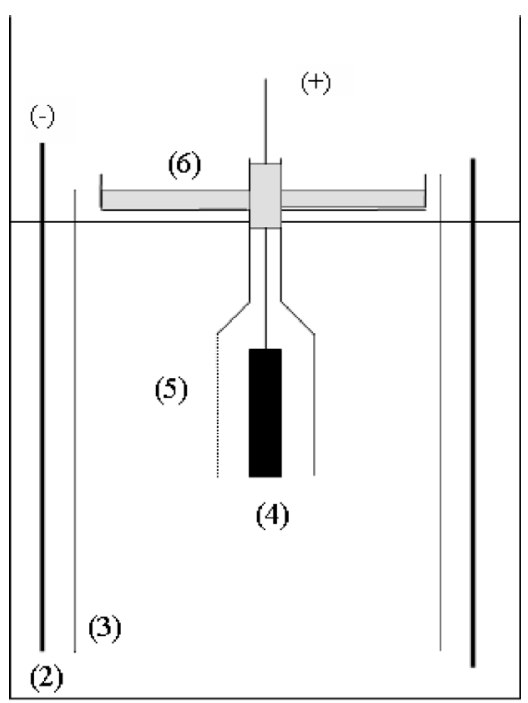

(1)

Fig. 8. Schematic representation of the electrolysis cell: 1 , crucicle; 2 , stainless steel electrode; 3 , Ni grid; 4, carbon electrode; 5 , bell-shaped $\mathrm{Ni}$ grid; 6 , plateau to recover the molten $\mathrm{Li}$.

Fig. 9. Potential of the electrolysis cell (bold line) and current density applied (dashed line) versus the charge passed; cathode, Ni grid; anode, stainless steel; $S=2 \mathrm{~cm}^{2} ; T=460{ }^{\circ} \mathrm{C}$. redox process was lower than unity. Several reasons might be envisaged:

(i) The metallic lithium produced at the cathode dissolves partially in the salt as its solubility is close to $1 \mathrm{~mol} \%$ [30-34]. Therefore the efficiency of the process may decrease due to the electronic conduction in the molten phase.

(ii) The design of the electrolysis cell was not optimized and the recombination of $\mathrm{H}_{2}$ and $\mathrm{Li}$ may occur. Then it acts as a continuous source of $\mathrm{LiH}$.

\section{Conclusions}

In this work the basic electrochemical properties of lithium hydride dissolved in molten chlorides were measured at $425{ }^{\circ} \mathrm{C}$. The diffusion coefficient and the apparent standard potential were found close to 2.5 . $10^{-5} \mathrm{~cm}^{2} \mathrm{~s}^{-1}$ and $-1.8 \mathrm{~V}$ vs. $\mathrm{Ag} / \mathrm{AgCl}$, respectively. In addition the composition of the electrolyte was optimized to increase the hydride content in the molten bath up to $20 \mathrm{~mol} \%$ at $460{ }^{\circ} \mathrm{C}$. Electrolysis tests at $460{ }^{\circ} \mathrm{C}$ over $24 \mathrm{~h}$ showed that $\mathrm{LiH}$ may be reprocessed in molten chlorides. 


\section{Acknowledgements}

The financial support of Cogema-Miramas is gratefully acknowledged. Dr. Deleuil from Cogema is thanked for the fruitful discussions within the course of this project.

[1] T. A. Ciarlariello and R. C. Werner, Chem. Eng. Prog. 57, 42 (1961).

[2] R.E. Shearer and R. C. Werner, J. Electrochem. Soc. 105, 693 (1958).

[3] G. N. Lewis, J. Am. Chem. Soc. 38, 774 (1916) (footnote).

[4] K. Moers, Z. anorg. allg. Chem. 113, 179 (1920) (in German).

[5] K. Peters, Z. anorg. allg. Chem. 131, 140 (1923) (in German).

[6] E. C. Potter and J. O'M. Bockris, Colloq. Int. Cent. Nat. Tech. Sci. (Electrolyse) 39, C3 (1952) (in French).

[7] J. A. Plambeck, J. P. Elder, and H. A. Laitinen, J. Electrochem. Soc. 113, 931 (1966).

[8] T. Takenaka and Y. Ito, Denki Kagaku 59, 759 (1991).

[9] H. Ito and Y. Hasegawa, J. Electrochem. Soc. 147, 289 (2000).

[10] T. Nohira and Y. Ito, J. Electrochem. Soc. 144, 2290 (1997).

[11] A. Kinoshita, T. Nohira, and Y. Ito, Extended Abstracts of the 149th ISE Meeting, 1998, p. 583.

[12] H. Qiao, T. Nohira, and Y. Ito, Electrochemistry 67, 643 (1997).

[13] H. Nakajima, T. Nohira, and Y. Ito, Electrochem. Solid-State Lett. 5, E17 (2002).

[14] T. Nohira and Y. Ito, J. Electrochem. Soc. 149, E159 (2002).

[15] H. Ito, Y. Hasegawa, and Y. Ito, J. Electrochem. Soc. 149, E273 (2002).

[16] P. Masset, J. Power Sources 160, 688 (2006).

[17] I.-M. Chou, S. M. Sterner, and K. S. Pitzer, Geochim. Cosmochim. Acta 56, 2281 (1992).
[18] D. Zeng, Ph. D. Thesis, Technical University of Bergakademie Freiberg, Germany 2003 (in German).

[19] P. Masset, J.-Y. Poinso, and J.-C. Poignet, J. Power Sources 137, 140 (2004).

[20] J. Sangster and A. D. Pelton, J. Phys. Chem. Ref. Data 16, 509 (1987).

[21] R. Littlewood, Electrochim. Acta 3, 270 (1961).

[22] L. Yang and R. G. Hudson, J. Electrochem. Soc. 106, 986 (1959).

[23] K. Kansaki and M. Takahashi, J. Electroanal. Chem. Interfacial Electrochem. 58, 339 (1975).

[24] A. J. Bard and L. R. Faulkner, Electrochemical Methods, Fundamentals and Applications, Wiley, New York 1980.

[25] H. J. S. Sand, Phil. Mag. 1, 45 (1901).

[26] P. Delahay, New Instrumental Methods in Electrochemistry, Interscience Publishers, New York 1954.

[27] C. P. Andrieux, I. Nadjo, and J. M. Savéant, J. Electroanal. Chem. 26, 147 (1970).

[28] J. C. Imbeaux and J. M. Savéant, Electroanal. Chem. Interfacial Electrochem. 44, 169 (1973).

[29] B. Y. Liaw, G. Deublein, and R. A. Huggins, J. Electrochem. Soc. 142, 2146 (1995).

[30] A.S. Dworkin, H. R. Bronstein, and M. A. Bredig, J. Phys. Chem. 66, 572 (1962).

[31] M. V. Smirnov and N. P. Podlesnyak, Zhurhal Prikladnoi Khimii 43, 1463 (1970).

[32] J. Liu, Ph. D. Thesis, National Polytechnic Institute of Grenoble, France 1988 (in French).

[33] T. Nakajima, Bull. Chem. Soc. Jpn. 47, 2071 (1974).

[34] J. Liu and J. C. Poignet, J. Appl. Electrochem. 20, 864 (1990). 